\title{
Sprogets forvandling
}

\author{
Om ord, ting og poesi i Paul la Cours \\ Fragmenter af en dagbog.
}

\section{HENRIK RASMUSSEN}

Fra antikken til i dag har der været en løbende sprogfilosofisk diskussion af forholdet mellem ord og ting, navn og benævnt. I 1976 forsøgte den franske litteraturteoretiker Gerard Genette at følge diskussionen i hele dens tusindårige forløb i bogen Mimologiques. Voyage en Cratylie. Genettes hovedpointe var, at forestillingen om en form for identitet mellem ord og ting ikke er fortidig, men lever videre i moderne tid, hovedsaglig i vores forestillinger om poetisk sprog.

Genettes resultater fra gennemgangen af nogle af modernis-. mens poetikker er umiddelbart funktionsdygtige over for andres refleksioner over poesien som erkendelsesvej og forholdet mellem sprog og verden. Denne artikels mål er at udvide Genettes projekt til at omfatte en poetik, der har været betydningsfuld for den danske digtning, nemlig Paul la Cours Fragmenter af en dagbog.

\section{Poesien som etisk fordring}

I Fragmenter af en dagbog, som blev trykt første gang i tidskriftet Heretica, årgang 1948, formulerede Paul la Cour noget grundlæggende om sin generations forhold til kunsten og poesien. Bogen blev det centrale manifest og lyriske inspirationspunkt for en generation af lyrikere gennem $40^{\prime}$ erne og $50^{\prime}$ erne.

La Cours ærinde med Fragmenter af en dagbog var - $\mathrm{i}$ tidens ånd - mere eksistentielt end blot litterært, og den poetik, som fremskrives i bogen, var mere et forsøg på en poetisk tilværelsesfors- 
tåelse end en håndbog for lyrikere. Litteraturen orienterede sig i efterkrigstiden mod det etiske og eksistentielle, hvilket udsprang af en desillusioneret mistro til den kultur, der havde frembragt to verdenskrige inden for få år. Ved en etisk selvbesindelse skulle mennesket genrejses i større værdighed.

La Cour fremskriver en livets poetik, det uudsigeliges poetik, hvis medium naturligt må være de små tilløb og tilnærmelser, med andre ord fragmentet. Poesien er hos la Cour intet mindre end det moment, der skal forvandle det i inhumanitet fortabte menneske til det genrejste menneske, for hvem poesien er et eksistensvilkår.

Bogens fragment- og aforismeform er desuden udtryk for en $i$ stoffet iboende vanskelighed med at formulere temaet. En vanskelighed, som går videre til ethvert forsøg på i akademisk form at behandle og diskutere bogens indsigter. Det er poesiens væsen fremfor dens fremtræden, la Cour forsøger at indfange og vise os; et væsen, der kun kan komme til syne i poetisk sprog. Fragmenternes egen form balancerer derfor mellem refleksion og poesi. Som fortolker af teksten står man i den situation - ganske som Sokrates i Platons Kratylosdialog - at tolkningens lethed er dens problem. La Cour synes at have sagt det hele i et eller andet fragment, og sandsynligvis har han formuleret det bedre end en selv.

Fra de hundredevis af fragmenter, hvis udsagn ikke altid stemmer overens ved første blik, er det muligt at uddrage nogle væsentlige forestillinger om poesien, dens forhold til tingsverdenen, dens erkendelsespotentiale og dens kulturelle nødvendighed. La Cours optegnelser betegner en bevægelse hen mod en grænse, hvor sproget slipper op og alt er liv, bevægelse og poesi, men som os andre sidder han uhjælpeligt fast i sproget og refleksionen.

\section{Poesien før sproget}

Fragmenter af en dagbog er udtryk for en trang til at besinde sig på det, som la Cour har gjort til grunden for sin eksistens, digtergerningen. Fragmenterne er "Overvejelser og Tilløb, efterhaanden som det blev mig nødvendigt at retfærdiggøre et Liv, levet for at skabe og befæste en poetisk Realitet" (s.7). ${ }^{1}$ Digtningen er udtryk for en trang til at holde sit liv op mod en absolut instans, 
retfærdigheden, og bogens ærinde kan således kaldes eksistentielt med en metafysisk længsel - en længsel mod en absolut etik. Det var blevet la Cour nødvendigt at vise, at det "at beskæftige sig med Poesi saa langt fra at være en Flugt, tvært imod er en høj og uundværlig Gerning i Tingenes Hjerte"(s.7). Han ville vise, at digtningen ikke er et rent æstetisk foretagende, men udtryk for en søgen efter sandhed, en søgen efter virkeligheden i stedet for en flugt fra den.

Tilskyndelsen til denne selvforklaring var den meget nærværende verdenskrig, som gjorde det ondes eksistens til vigtigste tema og "generationens fællesoplevelse" - som Bjørn Poulsen udtrykte det i Heretica (nr.4, 1948). Det var tiden for overvejelser over menneskenaturen i det etiske felt mellem det gode og det onde. Overvejelser der for Heretica-generationen blev en søgen efter en etisk målestok uden for mennesket.

At frembringe poesi fremhæves fra første side som et "værn mod menneskenaturens forvanskning" (s.7). La Cours søgen efter det gode knyttes til en forestilling om at genoprette en eller anden tabt form for autenticitet, renhed og værensfylde. Poesiens potentiale som middel til menneskets befrielse består $i$ at besejre larm med stilhed, og heri ligger en af grundideerne i la Cours poetik, at poesien sprogliggiort har en befriende, forvandlende funktion, men poesiens væsen er førsprogligt, ren væren. Han klager over sprogets utilstrækkelighed med hensyn til at udtrykke "en indre Sandhed". Han længes mod en poesi, der ikke er bundet til sprogets former, men „kan forlade alle Former og gaa nøgen og forsvarsløs ud i Verden" (s.9).

Ved at forstå poesien som førsproglig introducerer la Cour en skelnen mellem digtet og poesien. Digtet forstås som et kompleks af litterære konventioner, hvorimod poesien forstås som en asproglig oplevelse af sammenhæng i verden. Digtet er stedet, hvor poesien i heldigste fald kan vise sig, som la Cour formulerer det i sin definition af det poetiske digt - ,en Strøm af Ordforbindelser, gennem hvilken Poesien lader sig til Syne" (s.15).

Således må poesien forstås som noget eksisterende uden for det enkelte menneske omend ikke uafhængigt af mennesket, når poesien "lader sig til syne", er det udtryk for en slags handling eller drift, som er tilstede i verden, ikke ud af en menneskelig viljesakt. Poesien er en eksistensform, som bærer den værdi, den højeste af alle, at verden - forstået som sammenhæng - får reali- 
tet for os (s.9). Det er digtets mål at erkende og opfylde denne eksistensform.

\section{Båndet til naturen}

Naturen er karakteriseret ved sammenhæng, varighed, gentagelse og identitet mellem form og liv. Naturens former er mennesket hellige, netop fordi naturens former ikke kan miste denne identitet og blive usande. Over for naturen - og adskilt derfra står mennesket, hvis vilkår det er at skabe former, som mister deres gyldighed, døde former. Denne kløft mellem menneske og natur er ifølge la Cour kunstens drivkraft.

Kunsten er en stræben efter at skabe en enhed mellem form og liv, og hvor det lykkes, er det poesiens tilsynekomst. Den poetiske form er den eneste form, der „i lykkelige Øjeblikke berørtes af Sammensmeltningens Finger. Lynet som gennemfarer den poetiske Kunst" (s.16). Vores menneskelige vilkår er at søge at udtrykke denne enhed mellem os og naturen, at erkende enheden, som består på trods af vores fortolkende og dermed distancerede forhold til naturen. Det er en enhed, vi kun kan ane, et udtryk for liv, vi kun kan fange eet sted, i poesien.

Poesiens mål er ikke den fuldendte naturgengivelse. Kunsten er vores menneskelige skaberværk, den udtrykker med la Cours ord en "åndfuld Kunstsandhed", som ikke er identisk med naturen, men en sandhed om vores væren i verden. Der er tale om efterligning på et andet plan end den ydre realitet. Kunsten fikserer den levende forbindelse mellem bevidstheden og yderverdenen.

Når la Cour nærmer sig poesien væsen, må han i sit udtryk gribe til poetisk sprogbrug og således tale om „Vækstens umærkelige Gestus". Poesien, må han konstatere, er ikke et synligt mål, men en bevægelse, en vej til det tabte menneske, en vej til en underfuld verden, en vej til en lysende virkelighed (s.18).

\section{Kratylos og Hermogenes}

Diskussionen om sprogets forhold til det beskrevne kan spores tilbage til en af Platons dialoger, Kratylos. Det er en dialog mellem to sprogfilosofiske positioner - som Gerard Genètte betegner den konventionalistiske og den naturalistiske - forsvaret af hen- 
holdsvis Hermogenes og Kratylos.

For Kratylos er sproget naturalistisk i den forstand, at der eksisterer en overensstemmelse mellem den enkelte ting og dens navn: „Enhver af de eksisterende ting af Naturen har et navn, der retteligt tilkommer netop den" (s.11). ${ }^{2}$ Der er en naturlig sandhed eller rigtighed i navnene, en form for identitet. Heraf følger at der kun er rigtige navne, da et forkert navn intet navn er, blot en uforståelig lyd. Sproget er en perfekt overlejring af alt eksisterende, det er guddommeligt, gudsgivet.

Hermogenes hævder derimod, at sproget er ren menneskelig konvention. Navnene henviser til tingene, ikke ved en lighedsrelation, men simpelthen ved at menneskene har valgt at enes om et navn. Selve den lydlige form er tilfældig. Hovedargumentet for konventionalismen er, at der eksisterer forskellige sprog, der er velfungerende og har en indre logik, dvs. alle navne er lige gode, det er blot et spørgsmål om konsensus.

I striden mellem de to inddrages Sokrates, som efter anmodning undersøger problemet. Sokrates holder først med Kratylos, idet han med en lang række etymologiske undersøgelser af græske ord viser disse navnes "naturlige rigtighed “. I dialogens anden og betydelig kortere del tager Sokrates derimod Hermogenes' parti, idet han argumenterer for, at Kratylos' naturalisme, gør det umuligt at skelne mellem ting og navn, eftersom den i yderste konsekvens hævder fuldstændig identitet imellem dem. Til slut konkluderer Sokrates, at vejen til erkendelse af tingen ikke går gennem sproget, men gennem tingen selv, og at en undersøgelse af navnenes oprindelse og "rigtighed" så langt fra er afsluttet. I naturlig forlængelse heraf foreslår han, at de alle tre tager en tur på landet.

Dialogen er traditionelt blevet udlagt således, at Sokrates - og dermed Platon - forsvarer det naturalistiske synspunkt, og at den afslutningsvise omvending, der kun fylder et par sider, kan overses. Derimod har flere moderne fortolkere set forfægtelsen af Kratylos' synspunkt som en ironiseren over sofismen, hvorigennem Sokrates udtrykker Platons egentlige synspunkt, nemlig konventionalismen. Genette viser, at Sokrates ved sin argumentation indtager en tredie position, selv om han ikke eksplicit formulerer den.

Sokrates går i sin undersøgelse uden om spørgsmålet om navnenes oprindelse. Derimod tager han en række navne, opdeler 
disse efter delbetydninger og forsøger gennem en forklaring af delene at vise navnets motivation, dets naturlige rigtighed. Derved forskyder han interessen fra spørgsmålet om identitet til spørgsmålet om motivering.

At denne indirekte motivation ikke leder til navnets naturlige rigtighed fører Sokrates over i et forsøg på at opstille en fonetisksymbolsk tavle. Naturalismen forsøges forklaret ved at afmontere navnene til de mindste bestanddele for at knytte identiteten mellem lyd og ting på dette plan. Fonemet skulle lydligt mime tingen, ikke tingen som fremtræden, men tingen som væsen.

Her springer Sokrates' argumentation fra en indirekte motivation af navnene til den direkte motivation. Det er hypotesen om, at imitationen af hvert objekts væsen foregår ved hjælp af bogstaver og stavelser, der er Sokrates' specifikt egen. Ved at påvise at fonemerne optræder $\mathrm{i}$ ord af samme betydning, sandsynliggør han sin hypoteses rigtighed, men samtidig løber han ind i undtagelsens problem. Ordene indeholder ikke de stavelser, de burde. Her ender Sokrates sin gennemgang i en position, hvor han som udgangspunkt har taget sprogets naturalisme, men samtidig må konstatere, at sproget ikke lever op til denne:

Jeg er bange for, at det i Virkeligheden - som Hermogenes siger, bliver daarlige Forklaringer af Ordene, naar man skal slæbe paa den Theori om Ligheden, man bliver vist nødt til at tage Aftale til Hjælp for at forklare sig Ordenes Rigtighed, selv om den Forklaring er knapt saa fin som Lighedstheorien. (Sokrates, s.73)

Genette kalder derfor Sokrates en skuffet kratylist, der adskiller sig fra Kratylos ved ikke at tro på en sprogets paradistilstand. Hans position udvikles i en dialog med det eksisterende sprog. Han tror på sprogets mimetiske kapacitet og foretrækker denne tro på forbindelsen mellem sprog og verden, men enten har navngiveren $i$ tidernes morgen givet et falsk navn, eller også er navnet ikke blevet opdaget. Navngivningen er ikke slut, ej heller udforskningen af navnenes betydning. Samtidig kan Sokrates ikke acceptere den følge, konventionalismen får for erkendelsen. For hvordan kan der eksistere absolut erkendelse, hvis et udtryk ikke har en fast betydning? Sprog-relativeringen bliver et erkendelsesproblem, en problematik Sokrates berører og tager konsekvensen af, når han siger, gå til tingen selv. 


\section{Fra antikken til modernismen}

Fra ord / ting-debattens 'urtekst' - Kratylos - bevæger Gerard Genette sig frem i tiden over Augustin, Wallis, Donne og Leibniz til sprogproblemets behandling hos moderne poeter og prosaister, blandt andre Stephane Mallarmé, Paul Valéry og Jean-Paul Sartre.

Genette ser nærmere på Mallarmés overvejelser over sproget i „Mots Anglais" og "Petite Philologie“ og finder en åbenlys parallel til antikkens 'kratylisme', men også en forskydning, som skal vise sig tidstypisk - moderne.

Ud fra Mallarmés overvejelser over det engelske sprog fremgår det, at han tror på ordenes mulighed for at være 'rigtige', omend han skuffes over sprogets mangelfuldhed. Igen er det fonemet, som bærer betydningen, mens ordet ikke er identisk med tingen. Han drager en lidt anderledes konsekvens end Sokrates, idet han ser digtet som stedet, hvor sandheden om tingenes væsen kan udtrykkes. Ikke ved at digteren navngiver rigtigt, men gennem en kompenserende forskydning fra ordniveau til versniveau:

Poesien korrigerer ikke sproget, den kalder ikke nat for dag eller omvendt, men poesien kompenserer på andre måder, på andre niveauer ('højere niveauer') end sprogniveau ... hvilket for Mallarmé altid er ordniveau (s.274). ${ }^{3}$

I digtet kan digteren udtrykke sandheden om verden. Her reetableres kunstigt et idealt sprog. Sproget er utilstrækkeligt, men verset kan hæve sig i idealitet og perfektion. Hermed er Mallarmé hermogenist på sprogets vegne, men kratylist på versets. Ved at foretage denne forskydning fra ordniveau til vers-niveau, har Mallarmé introduceret en tvedeling af sprogfunktionen, sprog som kommunikation skilles fra poetisk sprog.

Valéry har tilsyneladende frigjort sig fra enhver tanke om, at sproget kan være naturalistisk. Ordene besidder for ham een lyd og een betydning, og der eksisterer ingen forbindelse mellem disse. Sprogets konventionalisme er ikke en tragisk erkendelse, men fremstilles som en kvalitet ved sproget. Således skriver han, at "det sande sprog begynder med det arbitrære tegn" (s.282). Dette skal forstås således, at det er kløften mellem sprog og verden, som konstituerer digterens poetiske råderum, identitet mellem ord og ting ville betyde poesiens død, den menneskelige mu- 
lighed for at skabe betydning opstår netop ved den differentierede sprogbrugs mulighed.

Valéry skelner - ligesom Mallarmé, men i mere udtalt grad mellem to sprogfunktioner: sproget som dagligt kommunikativt sprog og sproget som poetisk, sandhedsbærende sprog. Poesien ændrer sprogets funktion, det oversætter med en antik henvisning alment sprog til gudesprog. Valéry fuldfører dermed den opprioritering af det poetiske sprog, som Mallarmé begyndte.

Det, som kendetegner den poetiske sprogfunktion for Valéry, er, at den fremkalder en poetisk følelse hos læseren, hvorved enhver begivenhed, ethvert øjeblik, åbenbarer sig i sin musikalitet. Alle elementer resonerer i hinanden og korresponderer harmonisk. Det poetiske sprogbrug er midlet til „at producere eller reproducere en poetisk verden" (s.286). Der er tale om en æstetisk erkendelse af verden, en sanseåbning mod verden.

At digtet har denne evne til at fremkalde "en levende bevidsthed om forbindelser" (s.286) skyldes en kvalitet ved det poetiske sprog. Valery udtrykker kvaliteten ved et billede, pendulet: det poetiske udtryk svinger mellem sin betydning og sin lydlige form. Modsat den kommunikative sproghandling vil den poetiske meddelelse ikke opløse sig i ren betydning, fordi betydningen er uoversættelig. Den kan kun vise tilbage til sit udtryk. Tilegnelsen af digtet svinger evigt imellem udtryk og indhold, og betydningen vil reelt være uafsluttet. Der er således en uopløselig forbindelse mellem ordet som lyd og dets betydning.

Genette bemærker, at Valéry i sit grundsyn er konventionalist, men i forestillingen om det poetiske sprog bliver han neokratylist. Da netop den uopløselige forbindelse mellem ordet og dets betydning, tingen, kendetegner Kratylos' position.

Der er i Valérys poetik indskrevet et paradoks mellem en formalisme, der hævder den poetiske forms autonomi og en neokratylisme, der hævder lyd/betydning-sammenhængen. Et paradoks, Genette mener er typisk for mange moderne poetikker, og som kan aflæses i forståelsen af billedet - „l'image“, som poesiens sted. Da ordet er uden forbindelse med verden, bliver det poetiske billede, det poetiske udtryk par excellence i modernismen, bærer af det transcendentale potentiale. Ud af en dunkel forvandling transformeres det konventionelle tegn til et motiveret tegn i metaforen. 
Ved Genettes opfølgning af Kratylos-problematikken i moderne forestillinger om det poetiske sprog synliggøres nogle fælles, modernistiske forskydninger, som er funktionsdygtige over for en hvilken som helst poetik.

Der er en tendens til at fejre sprogets arbitraritet i stedet for at begræde den. Begrundelsen er, at mennesket derved bliver betydningsskabende i sproget, det bliver muligt at udtrykke sandheden om mennesket i verden. Et gudesprog ville være givet en gang for alle, det ville have udtømt verden og gjort betydningen endelig.

Samtidig opstår der en forestilling om sprogets dobbelte funktion, hvor en poetisk sprogfunktion kan kompensere eller overvinde det arbitrære tegn og blive et motiveret tegn. Poesien bliver derved erkendelsens sted. Der er ikke tale om en reetablering af et tabt gudesprog, men om en forskydning fra ordet til billedet som sandhedsbærende. I billedet indskrives mennesket som skaber. Om billedet skal forstås som en objektiv erkendelse, hvor ordet mirakuløst er forvandlet til realitet, eller som et sindbillede varierer. Men det poetiske billede får en ny central betydning som ikke-referentielt, sandhedsbærende udsagn.

Genette påviser en tilstedeværende neokratylisme bag megen moderne konventionalisme. Han fastslår, at poesien er blevet tilholdssted for metafysiske forestillinger om det absolut andet, som kan forvandle vores eksistens til poetisk eksistens, udfriet eksistens - den tidlige modernismes messianisme. Men som han pragmatisk og ganske rigtigt bemærker om længslen efter det poetiske liv:

Sproget, selv poetisk sprog - specielt poetisk sprog - har andet for end at imitere verden; for at parafrasere Proust, betegner den mimologiske drøm tærsklen til det poetiske liv, den kan vise os dette liv, meri aldrig konstituere det (s. 277).

\section{Ordene og tingene hos Paul la Cour}

Når man læser Fragmenter af en dagbog med opmærksomheden rettet mod forholdet mellem ord og ting, dagligsprog og poetisk sprog, er resultatet en række udsagn, der ved første blik er indbyrdes modstridende. Umiddelbart lægger la Cour afstand til den naturalistiske sprogposition, men også han skelner mellem ordet i digtet og ordet uden for digtet: „Udenfor Digtet findes in- 
gen overensstemmelse mellem Ordet og dets Betydning, bortset fra visse Onomatopoietica i Sproget" (s.89).

Ordet - i daglig brug - er hos la Cour i sig selv betydningstomt og tilfældigt, det er i menneskets konventionsbestemte brug af ordet som tegn for en ydre realitet, at betydningen opstår. Det er i mødet mellem den fortolkende bevidsthed og naturen, tingene, at betydningen skabes, for hos la Cour er også tingene i sig selv betydningstomme. Mennesket indgiver betydning i den tomme natur, „Naturen alene er Tom. Du skal bruge den til at genskabe Mennesket" (s.72).

La Cour synes at stå i en moderne subjektivisme, når han forankrer al betydning i den menneskelige bevidsthed. Han ser sproget som vores specifikt menneskelige middel til at skabe forbindelse mellem os og omverdenen. Sproget er selve det moment, der menneskeliggør vores eksistens, "dette Mirakel, der kaldte dig til Menneske" (s.89).

Sproget er udtryk for et fortolkende og erkendende forhold til verden, men også for vores længsel efter enhed med naturen. Menneskets anelse om og længsel efter naturens enhed er knyttet til sprogprocessen, men det er en uopfyldt længsel, naturen er som ren, ureflekteret væren uopnåelig for os.

På denne måde bliver sproget på en gang det, som adskiller os fra naturen, som udtryk for vores fortolkende forhold til omverdenen, og det udtryk, hvori vi giver vores længsel form, det middel vi søger den tabte enhed med. Ordet kan qua sin konventionelle karakter ikke udtrykke naturens væsen. Tingene har en uafvendelig tegnkarakter for mennesket, „om du kastede Ordene bort og skrev med Ting, ville også disse vise sig at være Tegn som kun Følelsen kan give Realitet" (s.75).

Mennesket er en uadskillelig del af betydningsdannelsen, men ikke sådan at forstå, at kun bevidstheden og dens fænomener har realitet, „Bedrag ikke dig selv: først var Tingene ... Og dog bor Poesien ikke i Tingene. Den bor i dig. Den er din Indgivelses Værk" (s.80). La Cour skelner mellem realitet og virkelighed, tingene $e r$, de har eksistens i virkeligheden uafhængigt af mennesket, men realitet får de først med menneskets væren iblandt dem og indgiven dem realitet med følelsen. 


\section{Ordene og poesien}

At digte er at indgive betydning, at sprogliggøre den poetiske forbindelse mellem individ og tingsverden. Sproget bliver et medierende punkt. Det, som skal indfanges i digt-sprogets net, er den poetiske sandhed. Denne sandhed er før-sproglig, men kan dog komme til syne i digtet. Det poetiske digt kan i denne forståelse sige det uudsigelige, udtrykke i sluttet form det uafsluttede i livet, bevægelsen, livsfølelsen.

Hvor sproget som et socialt bestemt system til kommunikation er bundet til tanken og logikken, vil la Cour med den poetiske sprogbrug udtrykke den erfaring, som er uopnåelig for tanken. I denne proces må selv den menneskelige vilje spille fallit, og poesien kommer som en selvstændig, upersonlig vilje, når man mindst venter det.

At sproget kan sige det uudsigelige følger af den opsplitning af sprogfunktionen, som også la Cour foretager. Der er en forestilling hos la Cour om sprog som kommunikation, dvs. som gennemgangsled for tanken, og om poetisk sprog, som ikke er gennemgangsled, ikke er beskrivende, men en autonom eksistens. Sproget som tankens og refleksionens redskab er udtryk for en reduktion af vores omverdenserkendelse, en reduktion der må kompenseres for. Een erkendelsesform erstattes af en anden, og poesiens mirakel er dens forbindelse til den asproglige sandhed:

Det poetiske Billede er gjort af Modsætninger, der ved at bringes sammen oplyser ikke blot hinanden, men alle Tings Sammenhæng og Enheden i det Liv, vi lever. (s.34)

Når sproget $\mathrm{i}$ den poetiske brug kan være udtryk for sandheden, må dẹtte være en eksistens i sig selv og ikke et henvisende udtryk, da dette jo ikke fanger tingenes væsen. I digtet sker en forvandling, hvorved det så at sige overvinder sin sproglighed. I poesiens billeder gendannes det konkrete, her forvandles "de abstrakte Forestillinger til konkrete Ting" (s.39). I formuleringer som denne ses det, at billedet også for la Cour er erkendelsens og sandhedens sted.

Hvordan la Cours forvandling skal forstås, og hvorvidt sandheden er realitetens eller tingsverdenens sandhed, det er de centrale punkter for forståelsen af hans placering mellem Kratylos og Hermogenes. 
Sproget i daglig brug udtrykker en dobbelt bevægelse, på den ene side en (ønsket) bevægelse mod erkendelse af tingens væsen og på den anden side en bevægelse væk fra det konkrete ind i abstraktionen. Sproget eller sprogliggørelsen af menneskets forhold til omverdenen er vores syndefald. Sproget er vores specifikt menneskelige træk og det træk, som samtidig er vores tragedie, adskillelsen fra naturlig væren. Det poetiske sprog - og kunst som sådan - er en vej tilbage til det konkrete, til identiteten mellem menneske og omverden. Den poetiske sprogfunktion er med la Cours ord en "udligning af et frafald”. Tilsyneladende helt på linie med Kratylos' sprogforestilling kan digteren „genoprette den tabte Inderlighed mellem Ord og Ting" og skabe et udtryk, hvor "Lyd og Betydning smelter sammen” (s.42 og s.92).

Som Genette viste, kan en opsplitning af sprogfunktionen forene en 'moderne' opfattelse af sproget som konvention med en tro på sprogets naturalistiske potentiale, realiseret i det poetiske sprog. Hos Valéry og Mallarmé sker der en paradoksal omvending i sprogopfattelsen begrundet $\mathrm{i}$ forestillingen om poetisk sprog og i glidningen fra ordniveau til billed- eller versniveau.

La Cour synes at fortsætte denne bevægelse, men stopper ikke ved dette greb til at omgå sprogets konventionalisme, han fortsætter sin argumentation til at gælde ordet. Dette sker ved at indføre betegnelsen „livsordet”, andre steder benævnt det kultiske ord. Ikke nok med at billedet opfattes som stedet, hvor det arbitrære tegn bliver motiveret, det enkelte ord kan åbenbart forvandles tilsvarende. „Med Livsordet smelter Lyd og Betydning saa inderligt sammen, at du tror at staa overfor et nyt Onomatopoieticon" (s.92).

La Cour synes i sådanne formuleringer at være Kratylist ikke bare i Valery'sk forstand, men i antik forstand. Med livsordet synes gudesproget at være genopstået. Sammenholder man dette med udgangspositionen, konventionalisten la Cour, forekommer hans position selvmodsigende ind i det absurde. Ordet har ingen forbindelse med det, som det betegner, og dog er visse ord så poetiske, at de smelter sammen med deres betydning. Men denne paradoksale position er kun tilsyneladende, fordi la Cours begrebsverden har foretaget en glidning, som allerede antydet i hans skelnen mellem virkelighed og realitet. 


\section{Ordene og sandhedserkendelsen}

Livsordet eller det kultiske ord kan opfattes som en genoprettelse af et gudsgivet sprog, et naturalistisk sprog, hvor ordet knyttes ved et identitets-slægtskab til tingen, tingen som væsen; som idé og ikke som fremtræden.

Det er her, at la Cour trækker tæppet væk under en læsning af hans poetik som kratylisme, for tingen som idé er ikke hos la Cour en objektiv eksistens, som det tænkes hos Platon. Ideen er forestillingen om tingen, tingens eksistens i bevidstheden, jf. formuleringer som den "„åndfulde Kunstsandhed" og tingens genopstandelse som „åndelig Forestilling“. Tingen har en dobbeltbetydning hos la Cour. Den inderlighed, som genoprettes, er mellem ordet og forestillingen om tingen. Tingen i digtet er et tegn, den er ikke tingen i-sig-selv, men tingen-i-dig: „Tegnet paa dens Liv i dig" (s.99).

Det, livsordet udtrykker, er forestillingen om tingens væsen, ordet er hos la Cour tegn - og altid tegn - for den konkrete ting, og vi "fylder Tegnet med al den Menneskelighed, det kan bære" (s.75). Derfor kan la Cour få sider efter introduktionen af livsordet skrive:

At Tingen, dens Definition og Ordets lyd forgæves raaber paa hinanden? Derfor kan intet Digt skrives med Ord alene, men med Ordenes Forbindelser med hinanden. (s.96)

Ordet er at forstå som tegn, og tegnets betydning er beroende på den menneskelige betydningstildeling. Den sandhed, vi kan nå, er aldrig uafhængig af vores bevidsthed, ej heller er den uafhængig af den ydre virkelighed, sansningen er dens forudsætning. Det er netop forbindelserne, dialektikken mellem de to, som udvikler og forvandler os.

Når man medtænker denne begrebs-tvetydighed i la Cours poetik, kan man se at hans sprogposition er kompleks og ny i forhold til de positioner, Genette fremlægger. Han fastholder verden som en af mennesket uafhængig virkelighed, og ender derfor ikke - som meget modernisme - i ren subjektivisme, selvom han fæstner sandheden i bevidstheden. Sandhedsbegrebet er derfor ikke absolut, metafysisk, men erkendelsen er heller ikke alene tilstede i bevidstheden, men opstår i en udveksling mellem sansning af tingsvierdenen og en begrebslig forståelse.

Herved lægger la Cour afstand til 20'er modernismen, f.eks. 
surrealismen, som han tidligere havde ladet sig inspirere af. Kunstudøvelsen var for surrealisterne forbundet med blindt at underkaste sig det ukendte i bevidstheden - det ubevidste, begæret, drømmen, kræfter, som la Cour mener må underkastes bevidst formgivende kontrol. La Cour giver surrealisterne ret $i$, at realiteten er at finde i bevidstheden, men han mener, de glemmer sansningen. Hvor de kan enes om at erklære døds- og kærlighedsdriften for poesiens understrøm, er svaret for surrealisterne at underkaste sig dette diktat og for la Cour at søge at beherske dem.

La Cour lægger afstand til den terroristiske holdning mod fornuften, som er surrealismens udgangspunkt. Hans position, der delvist er et brud med hans tidligere, skal nok ses i lyset af fascismen, hvis mobilisering af ubevidste lag i masseforførelsen og destruktionens tjeneste synes at have miskrediteret det ubevidste, drifternes frigørelse, som det menneskeliges utopiske moment en gang for alle. Der ligger hos la Cour en distance til den lovprisning af det andet, som den tidlige modernisme er fælles om og som begyndte hos Mallarmé.

\section{Forvandlingens bud}

Det vigtige for forståelsen af la Cours position er de medierende begreber, som skydes ind og forbinder det adskilte: tegnet mellem ting og ord, sproget som poetisk sprog (billedet) mellem ydre og indre verden, realiteten mellem bevidsthed og tingsverden og ånden mellem upersonlig drift og reflekteret form- og ordensdrift.

Forvandlingen, som man først kunne tro var en ydre forvandling fra ordet som konventionelt tegn til ordet som motiveret tegn, en transcenderende bevægelse ind til tingenes væsen, er nu afsløret som en indre forvandling: „Tegnets inderste Budskab til dig er altid det samme: Du må forvandle dig" (s.79). Digtets mål er det punkt, hvor jeg'et kan opleve sin enhed med omverdenen, et sammensmeltningspunkt, hvor tanken og følelsen forenes som erkendelsesvej. At denne erkendelse af sammenhæng bliver et forvandlingspunkt er selve digtets eksistensberettigelse.

I digtet kan vi ikke bare trøste vores længsel efter naturen eller vores tørst efter en æstetisk tilfredsstillende harmoni, det er erkendelsen som startpunkt for en forvandling, som vi i vores 
formdrift søger. La Cour overvinder dermed sin længsel ud over sproget og refleksionen mod at blive eet med naturen, sproget bliver forvandlingspunkt for mennesket, som hæver sig over naturen, bliver ånd. Digtet og enhver kunst-handling er en dialektik mellem at fæstne det flydende, vores væren i verden, livet, og at lære forandringens erkendelse. Kunsten „viste dig dine Maal ... Du er ikke længere uvidende om den, du kunde være."

Poesien har derfor stadig et messiansk moment, omend det ikke er metafysisk. Det er erkendelsens bevægelse, som skal udfri mennesket, og „,et Menneske, som har en Viden mere, lader sig ikke blot tænke, på ham hviler al Kultur, selve Menneskets Eksistens som Menneske."

Sprogets overvindelse i det poetiske udtryk, som hos Valéry m.fl., er ikke nødvendig for la Cour. Ved at åbne sig for poesien og erkendelsen den bringer, kan sproget blive stedet, hvor betydningen og realiteten opstår, uden at en transcendens til tingsverdenen sker.

Forvandlingen er nøgleordet bag la Cours poesi-begreb. Idet vi i digtet fæstner en eksistens-mulighed i poesien, kan vi vælge at realisere, hvad der først var en poetisk utopi. Poesiens bud er, at du må søge at overskride det faktiske og indgå i naturens orden, hvor alt er vækst og skabelse. At digte er for la Cour ensbetydende med hengivelse og kærlighed. Han insisterer på, at poesiens vej altid vil føre til medmennesket.

La Cour balancerer med sit komplekse standpunkt mellem at forvandle poesien til metafysisk størrelse og at forvandle verden til et rent bevidsthedsfænomen. Ved at fastholde sansningen af tingsverdenen undlader han at gøre sandheden helt subjektiv. Samtidig fæstner han poesien i mennesket, det er vores indgiven tingene realitet.

Det er en position, der fremkaldte kritik i samtiden. Poul Schmidt beskyldte i en anmeldelse la Cour for at tro, at han skabte tingene, når han nævnte dem, og Thorkild Bjørnvig efterlyste en erkendelse af, at naturen er betydningens sted, ikke mennesket, naturen som et metafysisk rum, vi kan åbne os for (Heretica nr. 1, 1951).

Digteren kan, som Genette skrev, føre os til det poetiske livs tærskel, men aldrig skabe og realisere dette liv. Paul la Cour indså, at bevægelsen er vigtigere end målet, bevægelsen mod at etablere et poetisk forhold til tingene, naturen og medmennesket, 
et kærlighedsforhold. At befæste den poetiske eksistens er et Sisyfos-arbejde, men livet værd. Det er livets bud, skabelsens og vækstens bud, man følger.

\section{Noter}

1. Citater fra følgende udgave: Fragmenter af en dagbog, København 1948.

2. Citater fra Platons skrifter, Bind 3, red. Carsten Høeg m.fl.

3. Citater fra Gerard Genette: Mimologiques. Voyage en Cratylie, Paris 1976 - $\mathrm{i}$ egen oversættelse. 